\title{
Prokinetic Activity of Ethanolic Extracts from Dried Citrus unshiu Peels in Mice
}

\author{
Hyun-Tai Lee* \\ Department of Life Science \& Biotechnology, Dong-eui University, Busan 614-714, Korea
}

Received December 22, 2013 /Revised January 1, 2014 / Accepted January 1, 2014

\begin{abstract}
Dried Citrus unshiu peels (Aurantii Nobilis Pericarpium; ANP) are used as a traditional folk medicine for the treatment of gastrointestinal (GI) motility disorders in East Asia, including Korea. In the present study, an ethanolic extract of ANP (ANP-E) exhibited no significant toxicity in mice, even at an oral dose of $5 \mathrm{~g} / \mathrm{kg}$. The effects of ANP-E on GI motor function were investigated by measuring the intestinal transit rate (ITR) of Evans blue in normal mice and mice with experimental GI motility dysfunction (i.e., peritoneal irritation by acetic acid; PIA). In normal mice, ANP-E significantly increased the ITR in a dose-dependent manner. The ITR in the PIA mice was significantly retarded compared to that in the normal mice. However, ANP-E significantly inhibited this retardation in a dose-dependent manner. Furthermore, in all the models, the potency of ANP-E appeared to be same or higher than that of cisapride, which was used predominantly for the treatment of various GI motility disorders in humans in the 1900s but was removed from the market in 2000 due to fatal side effects. The results suggest that ANP-E has potential as a new prokinetic agent that could be used as a substitute for cisapride.
\end{abstract}

Key words : Aurantii Nobilis Pericarpium, cisapride, gastrointestinal motility, intestinal transit, prokinetic agent

\section{서 론}

진피(Aurantii Nobilis Pericarpium; ANP) 및 청피(Citrii Unshiu Pericarpium; CUP)는 각각 운향과(Rutaceae) 상록 소 교목인 귤나무(Citrus unshiu Markovich)의 성숙 및 미성숙 과 피를 건조한 한약재로서, 대한민국을 비롯한 동아시아에서는 오래 전부터 이들 한약재를 고창(tympanites), 오심(nausea), 구토(vomiting), 소화 불량(dyspepsia) 등 다양한 소화기계 질 병의 치료에 널리 활용해 왔다 $[9,15]$. 물론, 이들 한약재의 전 통적인 용도는 소화기계 질병에 국한되지 않고, 기관지 천식 치료 및 심장 혈액 순환 개선 등 다양한 방면으로 활용되어 왔다 $[4,20]$. 진피 및 청피 추출물은 현재 국내 일반 의약품 시장에서 위장관 운동 기능 개선 생약 제제의 주요 성분으로 요긴하게 활용되고 있으며, 이들 추출물의 권장 일회 투여 용 량은 0.5-15 g로 알려져 있다[9]. 이렇듯 진피 및 청피 추출물이 위장관 운동 기능 장애를 치료하는 데에 동양 의학적으로 광 범위하게 쓰이고 있음에도 불구하고, 이들 추출물이 위장관 운동 기능에 미치는 효과에 대한 서양 의학적인 연구 성과는 아직 미미한 실정이다.

\section{*Corresponding author}

Tel : +82-82-51-890-1534, Fax : +82-82-51-890-1532

E-mail : htlee@deu.ac.kr

This is an Open-Access article distributed under the terms of the Creative Commons Attribution Non-Commercial License (http://creativecommons.org/licenses/by-nc/3.0) which permits unrestricted non-commercial use, distribution, and reproduction in any medium, provided the original work is properly cited.
진피 및 청피에 대한 기존의 서양 의학적 연구 결과들을 살펴보면, 항알레르기[10, 17], 항암[14], 항세균 및 항진균[8], 항바이러스[19], 항염증 $[11,15]$, 항산화[3, 7, 21], 항당뇨[16], 그리고 지질 저하 효과[20] 등이 보고된 바 있다. 하지만, 진피 및 청피가 위장관 운동 기능에 미치는 영향에 대해서는, 본 연구의 선행 연구에 해당하는 진피 및 청피 열수 추출물이 위장관 운동에 미치는 효과에 대한 보고[18] 이외에는 전무하 다. 또한, 진피 및 청피 함유 성분으로 알려진 hesperidin, limonene, naringin, nobiletin, poncirin, synephrine 등 [9]에 대 한 다양한 생리 활성들이 보고되었으나, 이들 성분의 위장관 운동 기능 관련 효과에 대해서는 역시 아직 보고된 바 없다.

한편, 20세기 말 최고의 위장관 운동 촉진제로 각광 받았으 며 수술 후 장폐색(postoperative ileus)을 비롯한 다양한 위장 관 운동 저해 상황에서 임상적으로 광범위하게 적용되었던 cisapride는, 심장 부정맥을 유발하는 심각한 부작용이 드러나 는 바람에 2000년 이후 판매가 중단되고 말았다[2]. 이후, cisapride 구조 유사체들을 중심으로 몇몇 위장관 운동 촉진제들 이 개발되어 시장에 등장하긴 했지만, 이전 cisapride의 위상 을 대신할 만큼의 강력한 약효를 나타내는 제품은 아직 출현 하지 않고 있다.

본 연구에서는, 다양한 위장관 운동 기능 저해 상황에서 전 통적으로 널리 사용되어 온 진피 및 청피가 실제로 위장관 운동 기능에 어떠한 영향을 미치는지 알아보고자 하였다. 이 를 위하여, 먼저 이들 한약재의 주정 추출물을 제조하여 각각 ANP-E (진피 주정 추출물) 및 CUP-E (청피 주정 추출물)로 명명하였으며, 이들이 공통적으로 함유하는 기지 물질들 중 
hesperidin을 지표 성분으로 삼아 HPLC 정량 분석을 실시함 으로써 ANP-E 및 CUP-E에 대한 품질 보증 data를 확보하였 다. 다음으로 mouse를 대상으로 단회 투여 경구 독성 시험을 실시하여, ANP-E 및 CUP-E의 급성 경구 독성 유무를 확인하 였다. 독성 시험을 통해 안전성이 보장된 ANP-E 및 CUP-E가 위장관 운동 기능에 미치는 영향을 검정하기 위하여, 정상 및 위장관 운동 기능 저해 상황에서 각각 mouse의 위장관 이송률 (intestinal transit rate; ITR)을 측정하였다. 또한 그 수치를 cisapride의 결과값과 비교함으로써, 이들 추출물이 cisapride를 대체할 수 있는 새로운 위장관 운동 기능 개선제로 개발 가능 한지 여부를 판단하고자 하였다.

\section{재료 및 방법}

\section{식물 재료 및 추출물 제조}

본 연구에 사용된 진피(ANP) 및 청피(CUP)는 제주도 산으 로서 (주대한생약(부산, 대한민국)에서 구입하였다. 분쇄한 진 피 및 청피를 각각 $100 \mathrm{~g}$ 씩 삼각 플라스크에 담은 후, 주정 에탄올 $500 \mathrm{ml}$ 을 넣고 $40^{\circ} \mathrm{C}$ 에서 3 시간 sonication하는 방법을 3 회 반복하여 추출액을 얻었다. 이렇게 얻은 추출액을 여과, 감압 농축, 그리고 동결 건조의 과정을 거쳐 최종적으로 분말 상태의 추출물을 얻었다. 그 결과, 최종 건중량 $21.1 \mathrm{~g}$ (ANP-E) 및 $15.4 \mathrm{~g}$ (CUP-E)의 주정 추출물을 각각의 식물 재료 $100 \mathrm{~g}$ 으 로부터 얻을 수 있었다.

\section{시약}

본 연구에 사용된 ascorbic acid, cisapride, Evans blue, 그리 고 hesperidin은 Sigma-Aldrich 社(St. Louise, MO)로부터, glacial acetic acid, HPLC grade acetonitrile 및 methanol은 Fisher Scientific 社(Fair Lawn, NJ)로부터 각각 구입하였다.

\section{지표 성분 정량 분석}

ANP-E $(10 \mathrm{mg} / \mathrm{ml})$, CUP-E $(10 \mathrm{mg} / \mathrm{ml})$, 그리고 hesperidin $(0.01-10 \mathrm{mg} / \mathrm{ml})$ 을 각각 HPLC grade methanol에 녹여 $13 \mathrm{~mm}$ syringe-driven filter (Millipore Corp., Bedford, MA) 로 여과하였다. 시료 용액을 각각 $100 \mathrm{ml}$ 씩 HPLC 시스템에 injection하였으며, 이동상은 증류수(distilled water; DW), acetonitrile, 그리고 acetic acid (80:20:0.5, v/v/v)의 혼합 용액 을 $1 \mathrm{ml} / \mathrm{min}$ 의 유속으로 isocratic하게 흘려 주었다. HPLC 시스템은 Waters 社(Milford, MA)의 1525 binary HPLC pump와 2487 dual wavelength UV detector, 그리고 Phenomenex 社(Torrance, CA)의 C18 역상 column $(250 \mathrm{~mm}$ $\times 4.6 \mathrm{~mm}$, particle size $5 \mathrm{~mm}$ )로 구성되었으며, hesperidin은 $\mathrm{UV} 280 \mathrm{~nm}$ 에서 검출하였다. ANP-E 및 CUP-E에 함유된 hesperidin의 양은, 순차적으로 희석한 hesperidin 용액(0.01-10 $\mathrm{mg} / \mathrm{ml}$ )을 injection하여 얻어진 HPLC chromatogram들을 바
탕으로 검량선을 그려 정량하였다.

\section{실험 동물}

(주)샘타코(오산, 대한민국)에서 구입한 4 주령 ICR mouse를 동의대학교 자연과학대학 내 동물실에서 1 주일 이상 사육하 여 새로운 환경에 충분히 적응시킨 후 실험에 사용하였다. 동 물실은 온도 $25 \pm 1{ }^{\circ} \mathrm{C}$, 습도 $55 \pm 5 \%$, 조명 시간 $7 \mathrm{am}-7 \mathrm{pm}$ 의 환경 조건을 항상 유지하였으며, 실험 동물이 물과 사료를 자 유롭게 섭취할 수 있도록 하였다. 모든 동물 실험은 오전 10시 부터 오후 5시 사이에 수행되었다.

\section{단회 투여 경구 독성 시험}

본 실험은 식품 의약품 안전청(Korea Food \& Drug Administration)의 '의약품 등의 독성 시험 기준(식약청 고시 제2005-60호)'에 근거하여 수행되었다[13]. 체중 23-30 g의 ICR mouse를 18 시간 절식시킨 후, 암수 각각 55마리씩 총 110 마리 에 대하여 5 마리씩 암수 각각 11 군으로 군 분리를 실시하였다. 체중 측정 후, 각각의 군에 대하여 ANP-E 또는 CUP-E를 0, $250,500,1,000,2,000,5,000 \mathrm{mg} / 10 \mathrm{ml} / \mathrm{kg}$ 의 용량으로 경구 투여하였다. 투여 당일은 약물 투여 시점으로부터 $0,1,2,3$, 4,5 시간 후에 mouse의 상태를 관찰하였으며, 이튿날부터는 매일 1회씩 14일간 관찰하였다. 약물 투여 후 $1,7,14$ 일 경과 시점에서 mouse의 체중을 측정하였다. 약물 투여 시점으로부 터 14일 경과 후 mouse를 안락사 시킨 다음 부검을 실시하여 내부 기관의 이상 유무를 관찰하였다.

\section{시험 약물 투여}

ANP-E 및 CUP-E가 mouse 위장관 이송률에 미치는 영향 을 cisapride 투여 시와 비교하기 위하여, 다음과 같은 방식으 로 시험 약물을 투여하였다. 예비 실험 결과, cisapride를 경구 투여 $(0.1-30 \mathrm{mg} / \mathrm{kg})$ 하였을 경우 위장관 이송률(ITR)의 유의적 인 변화가 없었던 반면, 꼬리정맥에 정맥 내 주입(i.v.)한 경우 에는 ITR이 유의적으로 증가함을 알 수 있었다. 따라서, 본 연구에서 cisapride는 모두 i.v.로 투여하였다. 실험 동물은 무 작위로 대조군(vehicle 투여군), cisapride 투여군, ANP-E 투여 군, 그리고 CUP-E 투여군의 4 군으로 나누었다. 대조군에는 vehicle로서 $\mathrm{DW}$ 를 경구 투여하였고, 25 분 경과 시점에서 역시 vehicle로서 $0.57 \mathrm{M}$ ascorbic acid 용액을 i.v. 투여하였다. Cisapride 투여군에는 DW (vehicle) 경구 투여 후 25분 경과 시점에서 $0.57 \mathrm{M}$ ascorbic acid 용액에 녹인 cisapride를 각각 $0.1,1,10 \mathrm{mg} / \mathrm{kg}$ 의 용량으로 i.v. 투여하였다. ANP-E 및 CUP-E 투여군에는 두 시료를 각각 DW에 녹여 각각 $0.01,0.1$, $1 \mathrm{~g} / \mathrm{kg}$ 의 용량으로 경구 투여하였고, 25분 경과 시점에서 0.57 $\mathrm{M}$ ascorbic acid 용액(vehicle)을 i.v. 투여하였다.

\section{실험적 위장관 운동 기능 저해 상황 유발}

위장관 운동 기능이 저해되는 병태 상황을 mouse에서 실험 
적으로 유발하기 위해 peritoneal irritation by acetic acid (PIA) 방법을 활용하였다 $[5,18]$. 상기 설명한 대로 mouse에 시험 약물(또는 $\mathrm{DW}$ )를 경구 투여한 후 30 분 경과 시점에서 acetic acid $(0.6 \%, \mathrm{w} / \mathrm{v}$, in saline)를 $10 \mathrm{ml} / \mathrm{kg}$ 의 용량으로 복 강 내 주입(i.p.)하였으며, 이후 cage에서 개별적으로 30 분간 회복기를 주었다.

\section{위장관 이송률 측정}

본 연구에서는, 위장관 운동 기능을 측정하는 in vivo 실험 법 중 Evans blue 용액 $(5 \%, \mathrm{w} / \mathrm{v}$, in DW)의 위장관 이송률 (ITR)을 측정하는 방법을 사용하였다[12]. 체중 25-30 g의 수컷 ICR mouse를 약 20시간 절식시켰으며, 물은 자유롭게 마실 수 있도록 하였다. 시험 약물 용량 별로 각각 8마리씩의 mouse 에 대해 실험하였다. 정상 mouse의 경우 시험 약물(또는 DW) 경구 투여 후 30 분 경과 시점에서, PIA 유발 mouse의 경우 acetic acid i.p. 투여 후 30분 경과 시점에서, 각각 Evans blue $0.1 \mathrm{ml}$ 경구 투여하였다. Evans blue 투여 후 30분 경과 시점에 서 mouse를 안락사 시킨 다음 소장 전체를 적출하였으며, 장 간막을 포함한 소장 주변 조직들을 제거한 후 소장이 늘어나 지 않도록 주의하면서 신속하게 소장 전체를 일직선으로 배열 하였다. 소장 전체의 길이(유문부-맹장 입구; $\mathrm{cm}$ ) 및 Evans blue가 이동한 거리 $(\mathrm{cm})$ 를 자로 측정하여 ITR의 지표로 삼았 다.

ITR $(\%)=($ Evans blue가 이동한 거리/소장 전체의 길이 $)$ $\times 100$

\section{통계 처리}

모든 군의 실험 결과 수치는 평균 \pm 표준오차(mean $\pm \mathrm{SEM}$ ) 로 나타내었다. 군 간의 유의성 검정은 one way ANOVA 및 Student's $t$-test를 통해 이루어졌으며, $p<0.05$ 일 때 유의적인 차이가 있는 것으로 판단하였다.

\section{결과 및 고찰}

\section{ANP-E 및 CUP-E에 함유된 hesperidin의 정량 분석}

연구의 대상이 되는 시료가 천연물 추출물인 만큼, 이들의 품질을 보증하기 위한 객관적 지표를 확보하기 위해, 진피 및 청피에 공통적으로 함유된 것으로 알려진 flavanone glycoside인 hesperidin $[1,6]$ 을 지표 성분으로 삼아 HPLC 정량 분석을 실시하였다(Fig. 1). 검량선을 토대로 각 시료에 함유된 hesperidin 함량을 계산한 결과, 시료 $1 \mathrm{mg}$ 당 ANP-E에는 $53.50 \pm 1.04 \mathrm{mg}(r=3)$, CUP-E에는 $35.94 \pm 0.64 \mathrm{mg}(r F 3)$ 의 hesperidin이 함유되어 있는 것으로 나타났다. 이를 통해 본 연구 에 사용된 ANP-E 및 CUP-E의 quality control data를 확보할 수 있었다.

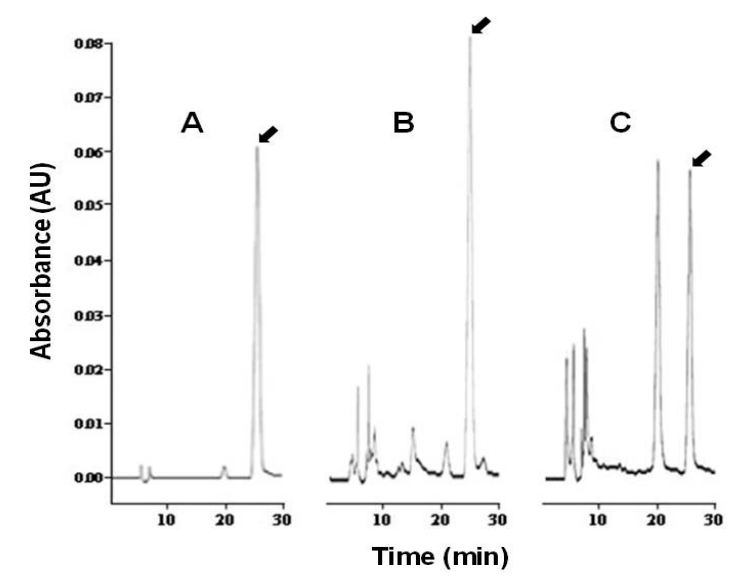

Fig. 1. Separation of hesperidin by reversed phase HPLC. Typical chromatograms of (A) standard hesperidin (50 $\mathrm{mg})$, (B) ANP-E (1 mg), and (C) CUP-E (1 mg), monitored at $280 \mathrm{~nm}$. Arrows indicate the hesperidin peaks.

\section{ANP-E 및 CUP-E의 mouse 급성 독성}

향후 신약 또는 기능성 제품으로의 개발을 위한 기본적인 안전성 data를 확보하기 위하여, ANP-E 및 CUP-E에 대한 단 회 투여 경구 독성 시험을 실시하였다(Table 1). 독성 시험에 쓰인 총 110 마리의 mouse 중 14 일의 실험 기간 도중 사망한 개체는 한 마리도 없었으며, 어떠한 이상 징후도 관찰되지 않 았다. 이는 ANP-E 및 CUP-E의 최소 경구 투여 치사량이 적어 도 최대 투여량인 $5 \mathrm{~g} / \mathrm{kg}$ 이상임을 나타내는 결과이다. 또한 해당 기간 동안의 체중 변화를 보면, 수컷이 암컷에 비해 상대 적으로 체중 증가량이 컸으며, 동성 내에서는 투여량에 상관 없이 모든 군에서 거의 비슷한 체중 증가 양상을 보였다. 14 일 째에 mouse를 안락사 시킨 후 실시한 부검 결과 역시, 어느 개체에서도 검안 상 이상 증상이 발견되지 않았다. 본 실험을 통하여, ANP-E 및 CUP-E는 $5 \mathrm{~g} / \mathrm{kg}$ 의 고용량 투여 시에도 급성 경구 독성을 나타내지 않는 비교적 안전한 물질임을 확 인할 수 있었다.

\section{ANP-E 및 CUP-E가 정상 mouse의 위장관 이송률에 미 치는 영향}

ANP-E, CUP-E, 그리고 cisapride를 각각 정상 mouse에 투 여한 후 위장관 이송률(ITR)을 측정하는 방식으로 이들 약물 이 위장관 운동에 미치는 효과를 비교-분석하였다(Fig. 2). 대 조군의 ITR은 $57.68 \pm 1.98 \%$ 이었으며, 이는 cisapride i.v. 투여 $(1-10 \mathrm{mg} / \mathrm{kg})$ 에 의해 유의적으로 증가되었다. Cisapride 투여 군의 경우, $1 \mathrm{mg} / \mathrm{kg}(68.97 \pm 3.83 \%)$ 투여 시의 ITR이 $10 \mathrm{mg} /$ $\mathrm{kg}(66.57 \pm 3.59 \%)$ 투여 시보다 높게 나타났다. 이는 기존의 연 구 결과들[12, 18]와 일맥상통하는 결과로서, 향후 대조 약물로 서의 cisapride 투여 용량은 $1 \mathrm{mg} / \mathrm{kg}$ 으로 결정하였다. ANP-E 투여군의 ITR은 각각 $58.57 \pm 3.17 \%(10 \mathrm{mg} / \mathrm{kg}), 62.30 \pm 3.88 \%$ $(100 \mathrm{mg} / \mathrm{kg}), 67.60 \pm 5.05 \%(1 \mathrm{~g} / \mathrm{kg})$ 로서 용량 의존적 증가 양 
Table 1. Mortality and clinical observations during 14 days, and body weight gain and necropsy findings on day 14 following oral administrations of various doses of ANP-E and CUP-E to mice

\begin{tabular}{|c|c|c|c|c|c|c|c|c|c|}
\hline \multirow{2}{*}{\multicolumn{2}{|c|}{$\begin{array}{c}\text { Dose } \\
\text { (g/kg, oral) }\end{array}$}} & \multicolumn{2}{|c|}{ Mortality $^{a}$} & \multicolumn{2}{|c|}{ Clinical signs } & \multicolumn{2}{|c|}{$\begin{array}{l}\text { Body weight gain (g) } \\
\quad(\text { mean } \pm \text { SEM })\end{array}$} & \multicolumn{2}{|c|}{ Necropsy findings ${ }^{c}$} \\
\hline & & M & F & M & $\mathrm{F}$ & $\mathrm{M}$ & $\mathrm{F}$ & M & $\mathrm{F}$ \\
\hline & 0 & $0 / 5$ & $0 / 5$ & $-{ }^{b}$ & - & $5.44 \pm 1.07$ & $3.34 \pm 0.47$ & $0 / 5$ & $0 / 5$ \\
\hline \multirow{5}{*}{ ANP-E } & 0.25 & $0 / 5$ & $0 / 5$ & - & - & $5.42 \pm 0.98$ & $3.58 \pm 0.37$ & $0 / 5$ & $0 / 5$ \\
\hline & 0.5 & $0 / 5$ & $0 / 5$ & - & - & $5.06 \pm 0.74$ & $4.16 \pm 0.64$ & $0 / 5$ & $0 / 5$ \\
\hline & 1 & $0 / 5$ & $0 / 5$ & - & - & $4.42 \pm 0.98$ & $3.52 \pm 0.42$ & $0 / 5$ & $0 / 5$ \\
\hline & 2 & $0 / 5$ & $0 / 5$ & - & - & $4.86 \pm 1.12$ & $2.96 \pm 0.51$ & $0 / 5$ & $0 / 5$ \\
\hline & 5 & $0 / 5$ & $0 / 5$ & - & - & $5.54 \pm 0.94$ & $3.40 \pm 0.40$ & $0 / 5$ & $0 / 5$ \\
\hline \multirow{5}{*}{ CUP-E } & 0.25 & $0 / 5$ & $0 / 5$ & - & - & $4.44 \pm 0.90$ & $2.68 \pm 0.28$ & $0 / 5$ & $0 / 5$ \\
\hline & 0.5 & $0 / 5$ & $0 / 5$ & - & - & $5.58 \pm 0.99$ & $4.34 \pm 0.47$ & $0 / 5$ & $0 / 5$ \\
\hline & 1 & $0 / 5$ & $0 / 5$ & - & - & $5.40 \pm 0.71$ & $3.18 \pm 0.41$ & $0 / 5$ & $0 / 5$ \\
\hline & 2 & $0 / 5$ & $0 / 5$ & - & - & $4.30 \pm 0.48$ & $3.44 \pm 0.84$ & $0 / 5$ & $0 / 5$ \\
\hline & 5 & $0 / 5$ & $0 / 5$ & - & - & $5.84 \pm 1.34$ & $3.36 \pm 0.32$ & $0 / 5$ & $0 / 5$ \\
\hline
\end{tabular}

M: male; F: female

${ }^{\text {a } V a l u e s ~ a r e ~ e x p r e s s e d ~ a s ~ n u m b e r ~ o f ~ d e a t h / t o t a l ~ n u m b e r ~ o f ~ a n i m a l s . ~}$

${ }^{\mathrm{b}}$ No clinical signs were observed during the period.

${ }^{c}$ Values are expressed as number of abnormal animals/total number of animals.

상을 나타내었다. 특히, ANP-E $1 \mathrm{~g} / \mathrm{kg}$ 투여 후의 ITR은 대조 군의 결과에 비해 유의적 높았으며, cisapride 투여군의 ITR 과 대등한 수준임을 알 수 있었다. 반면, CUP-E 투여군에서는 어떤 용량에서도 대조군의 ITR과 유의적인 차이가 나타나지 않았다. 따라서, CUP-E는 향후 수행된 병태 모델에서의 약효 검정에서 제외되었다.

\section{ANP-E의 위장관 운동 기능 저해 회복 효능}

정상 mouse에서 위장관 운동 촉진 효과가 확인된 ANP-E 가 위장관 운동 기능 저해 상황에서도 회복 효능이 있는지

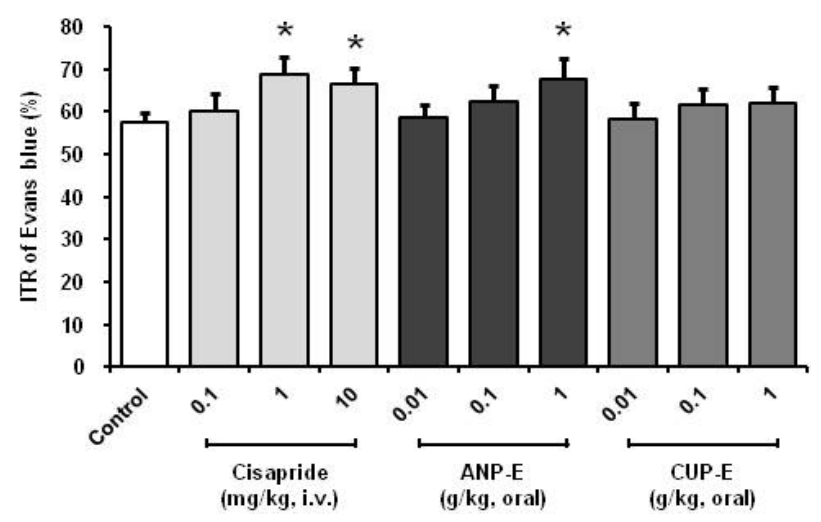

Fig. 2. Effects of cisapride, ANP-E, and CUP-E on ITR in normal mice. The ITR (\%) of Evans blue during a $30 \mathrm{~min}$ period following an oral administration of an Evans blue solution $30 \mathrm{~min}$ after pretreatment with each test drug in normal mice $[\pi=8$ for each bar, except for control (white bar, $n=18)]$. Significant difference $\left({ }^{*} p<0.05\right)$ compared with control.
알아보기 위하여, 실험적 위장관 운동 기능 저해 모델인 PIA mouse를 대상으로 시험 약물(ANP-E 및 cisapride)을 투여한

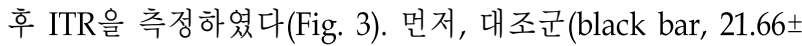
$4.10 \%$ )과 정상군(white bar, $57.84 \pm 3.23 \%$ )을 비교해 보면, 군 간의 ITR 수치 차이가 3 배 가까이 나는 것을 확인할 수 있다. 이는 기존의 연구 결과들 $[12,18]$ 와 일맥상통하는 결과이며, PIA에 의해 mouse의 위장관 운동 기능이 심각하게 저해되었

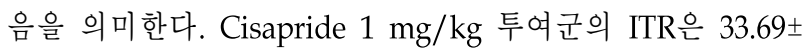
$4.32 \%$ 로서 대조군에 비해 유의적으로 높았으나, cisapride 투 여 mouse에서는 몸의 떨림 등 부작용으로 추측되는 이상 증상 이 관찰되었다. Mouse의 실험적 위장관 운동 저해 모델에서 cisapride i.v. 투여 시 나타나는 이러한 경련 등의 부작용은

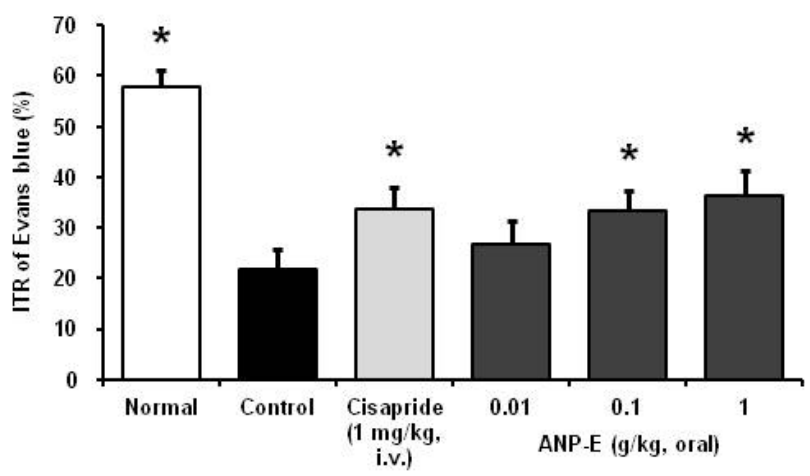

Fig. 3. Effects of cisapride and ANP-E on ITR in PIA mice. The ITR (\%) during a $30 \mathrm{~min}$ period following an oral administration of Evans blue $30 \mathrm{~min}$ after the induction of PIA in mice ( $I F 8$ for each bar). Significant difference $\left({ }^{*} p<0.05\right)$ compared with PIA control (black bar). 
이미 기존의 연구 결과들[12, 18]에서도 보고된 현상이며, 심한 경우 사망[12]에 이르는 개체도 발생한 것으로 보고된 바 있다. ANP-E 투여군의 ITR은 각각 $26.64 \pm 4.67 \%(10 \mathrm{mg} / \mathrm{kg}), 33.28$ $\pm 4.01 \%(100 \mathrm{mg} / \mathrm{kg}), 36.47 \pm 4.67 \%(1 \mathrm{~g} / \mathrm{kg})$ 로서 용량 의존적 증가 양상을 보였으며, $100 \mathrm{mg} / \mathrm{kg}$ 이상 투여 시 대조군에 비 해 ITR이 유의적 높게 나타났다. 또한, cisapride 투여 시 나타 난 이상 증상은 전혀 관찰되지 않았으며, cage 안에서의 회복 양상 역시 현저히 빨랐다. 이러한 결과들은, 위장관 운동 기능 저해 상황에서는 ANP-E의 회복 효능이 cisapride보다 양적으 로나 질적으로 모두 뛰어날 가능성이 있음을 시사한다.

이상과 같이, 본 연구에서는 진피 주정 추출물(ANP-E)이 정상 및 병태 상황의 mouse에서 모두 강력한 위장관 운동 촉 진 효과를 나타내었음을 최초로 보고하였다. 본 연구의 성과 를 요약하면, 우선 ANP-E는 $5 \mathrm{~g} / \mathrm{kg}$ 의 고용량에서도 급성 독 성을 나타내지 않았다. ITR 실험 결과, ANP-E는 정상 및 PIA 유발 mouse에서 모두 위장관 운동을 촉진시키는 것으로 나타 났다. ANP-E의 위장관 운동 촉진 효과를 cisapride와 비교해 보면, 정상군에서는 cisapride와 거의 대등한 ITR 수치를 나타 내었으며, 특히 위장관 운동 저해 상황에서는 cisapride보다 약효 및 안전성 측면에서 모두 비교 우위를 점하는 강력한 위장관 운동 기능 개선 효과를 보였다. 이는 서론에서 언급했 던 것처럼, 아직 출현하지 않고 있는 cisapride의 새로운 대체 의약품으로서ANP-E가 그 강력한 후보 물질이 될 수 있음을 시사하는 결과이다. 향후 ANP-E의 작용 기전에 대한 약리학 적 고찰, ANP-E로부터 유효 성분 분리 및 동정 등의 추가적인 연구를 통해, 인간의 위장관 운동 기능 저해 상황을 개선할 수 있는 새롭고 강력한 신약으로의 개발 가능성을 적극적으로 모색해야 할 것으로 사료된다.

\section{감사의 글}

이 논문은 2012학년도 동의대학교 교내연구비에 의해 연구 되었음(2012AA102).

\section{References}

1. Aturki, Z., Brandi, V. and Sinibaldi, M. 2004. Separation of flavanone-7-Oglycoside diastereomers and analysis in citrus juices by multidimensional liquid chromatography coupled with mass spectrometry. J Agric Food Chem 52, 53035308.

2. Baig, M. K. and Wexner, S. D. 2004. Postoperative ileus: a review. Dis Colon Rectum 47, 516-526.

3. Bocco, A., Cuvelier, M. -E., Richard, H. and Berset, C. 1997. Antioxidant activity and phenolic composition of citrus peel and seed extracts. J Agric Food Chem 46, 2123-2129.

4. Choi, I.-Y., Kim, S.-J., Jeong, H.-J., Park, S.-H., Song, Y.-S., Lee, J.-H., Kang, T.-H., Park, J.-H., Hwang, G.-S., Lee, E.-J., Hong, S.-H., Kim, H.-M. and Um, J.-Y. 2007. Hesperidin in- hibits expression of hypoxia inducible factor- 1 alpha and inflammatory cytokine production from mast cells. $\mathrm{Mol}$ Cell Biochem 305, 153-161.

5. Friese, N., Chevalier, E., Angel, F., Pascaud, X., Junien, J. L., Dahl, S. G. and Riviere, P. J. M. 1997. Reversal by $\kappa$ -agonists of peritoneal irritation-induced ileus and visceral pain in rats. Life Sci 60, 625-634.

6. Garg, A., Garg, S., Zaneveld, L. J. D. and Singla, A. K. 2001. Chemistry and pharmacology of the Citrus bioflavonoid hesperidin. Phytother Res 15, 655-669.

7. Jeong, S.-M., Kim, S.-Y., Kim, D.-R., Jo, S.-C., Nam, K. C., Ahn, D. U. and Lee, S.-C. 2004. Effect of heat treatment on the antioxidant activity of extracts from Citrus peels. J Agric Food Chem 52, 3389-3393.

8. Jo, C. R., Park, B. J., Chung, S. H., Kim, C. B., Cha, B. S. and Byun, M. W. 2004. Antibacterial and anti-fungal activity of citrus (Citrus unshiu) essential oil extracted from peel by-products. Food Sci Biotechnol 13, 384-386.

9. Kim, C. M., Shin, M. K., Ahn, D. G. and Lee, K. S. 1997. Chungyak Daesajun Vol. 8, pp. 4026-4030, Jungdam Publisher: Seoul, Korea.

10. Kim, D. K., Lee, K. T., Eun, J. S., Zee, O. P., Lim, J. P., Eum, S. S., Kim, S. H. and Shin, T. Y. 1999. Anti-allergic components from the peels of Citrus unshiu. Arch Pharm Res 22, 642-645.

11. Kim, K. S., Rhee, H. I., Park, E. K., Jung, K., Jeon, H. J., Kim, J.-H., Yoo, H., Han, C.-K., Cho, Y.-B., Ryu, C. J., Yang, H. I. and Yoo, M. C. 2008. Anti-inflammatory effects of Radix Gentianae Macrophyllae (Qinjiad), Rhizoma Coptidis (Huanglian) and Citri Unshiu Pericarpium (Wenzhou migan) in animal models. Chin Med 3, 10.

12. Lee, H.-T., Seo, E.-K., Chung, S.-J. and Shim, C.-K. 2005. Effect of an aqueous extract of dried immature fruit of Poncirus trifoliata (L.) Raf. on intestinal transit in rodents with experimental gastrointestinal motility dysfunctions. $J$ Ethnopharmacol 102, 302-306.

13. Lee, H.-T., Seo, E.-K., Chung, S.-J. and Shim, C.-K. 2005. Prokinetic activity of an aqueous extract from dried immature fruit of Poncirus trifoliata (L.) Raf. J Ethnopharmacol 102, 131-136.

14. Lee, S., Ra, J., Song, J.-Y., Gwak, C., Kwon, H.-J., Yim, S.-V., Hong, S.-P., Kim, J., Lee, K.-H., Cho, J.-J., Park, Y. S., Park, C.-S. and Ahn, H.-J. 2011. Extracts from Citrus unshiu promote immunemediated inhibition of tumor growth in a murine renal cell carcinoma model. J Ethnopharmacol 133, 973-979.

15. Oh, Y.-C., Cho, W.-K., Jeong, Y. H., Im, G. Y., Yang, M. C., Hwang, Y.-H. and Ma, J. Y. 2012. Anti-inflammatory effect of Citrus Unshiu peel in LPS-stimulated RAW 264.7 macrophage cells. Am J Chin Med 40, 611-629.

16. Park, H.-J., Jung, U. J., Cho, S.-J., Jung, H.-K., Shim, S. and Choi, M.-S. 2013. Citrus unshiu peel extract ameliorates hyperglycemia and hepatic steatosis by altering inflammation and hepatic glucose- and lipid-regulating enzymes in $d b / d b$ mice. J Nutr Biochem 24, 419-427.

17. Park, S.-H., Park, E.-K. and Kim, D.-H. 2005. Passive cuta- 
neous anaphylaxis-inhibitory activity of flavanones from Citrus unshiu and Poncirus trifoliata. Planta Med 71, 24-27.

18. Ryu, J. H. and Lee, H.-T. 2013. Effects of dried Citrus unshiu peels on gastrointestinal motility in rodents. Arch Pharm Res 36, 641-648.

19. Suzuki, M., Sasaki, K., Yoshizaki, F., Oguchi, K., Fujisawa, M. and Cyong, J.-C. 2005. Anti-hepatitis C virus effect of Citrus unshiu peel and its active ingredient nobiletin. $\mathrm{Am}$
$J$ Chin Med 33, 87-94.

20. Yang, G., Lee, J., Jung, E.-D., Ham, I. and Choi, H.-Y. 2008. Lipid lowering activity of Citri unshii pericarpium in hyperlipemic rats. Immunopharmacol Immunotoxicol 30, 783-791.

21. Yang, X., Kang, S.-M., Jeon, B.-T., Kim, Y.-D., Ha, J.-H., Kim, Y.-T. and Jeon, Y.-J. 2011. Isolation and identification of an antioxidant flavonoid compound from citrus-processing by-product. I Sci Food Agric 91, 1925-1927.

\section{초록 : 귤나무 과피 유래 한약재 주정 추출물의 위장관 운동 촉진 효과}

\section{이현태*}

(동의대학교 생명응용학과)

귤나무(Citrus unshiu)의 과피를 말린 한약재인 진피(Aurantii Nobilis Pericarpium; ANP)는 오래 전부터 대한민 국을 비롯한 동아시아에서 위장관 운동 관련 질환의 치료에 전통적으로 쓰여 왔다. 본 연구에서는 진피 주정 추출 물(ANP-E)을 제조하여 실험하였는데, 우선 ANP-E는 $5 \mathrm{~g} / \mathrm{kg}$ 의 고용량을 mouse에 경구 투여하였을 때에도 급성 독성을 나타내지 않았다. ANP-E가 위장관 운동 기능에 미치는 영향을 파악하고 이를 cisapride의 효과와 비교하 기 위하여, mouse를 대상으로 위장관 이송률을 측정하는 실험을 수행하였다. Cisapride는 20세기 말까지 다양한 위장관 운동 저해 상황에서 임상적으로 광범위하게 적용되었던 최고의 위장관 운동 촉진제였으나, 치명적인 부작 용으로 인하여 2000년 이후 시장에서 철수된 약물이다. 실험 결과, ANP-E는 정상 및 위장관 운동 저해 상황에서 모두 용량 의존적으로 위장관 운동을 촉진시키는 것으로 나타났다. ANP-E의 위장관 운동 촉진 효과를 cisapride 와 비교해 보면, 정상 mouse에서는 cisapride와 거의 대등한 위장관 이송률 수치를 나타내었으며, 특히 위장관 운동 저해 상황에서는 cisapride보다 약효 및 안전성 측면에서 모두 비교 우위를 점하는 강력한 위장관 운동 기능 개선 효과를 보였다. 이상과 같은 결과들은, ANP-E가 인간의 위장관 운동 기능 저해 상황을 개선할 수 있는 새롭 고 강력한 신약 후보 물질이자, 아직 시장에 출현하지 않고 있는 cisapride의 대체 의약품으로서 개발 가능함을 시사하고 있다. 